\title{
The Mendicity Society and Its Clients: A Cautionary Tale
}

\section{Lynn MacKay}

The general lineaments of the nineteenth-century moral analysis of poverty are well known: that given the opportunity many, if not most, of the poor would choose a life of easy dependence upon upper-class or public handouts. Consequently, social assistance, whether public or private, had to be carefully formulated at once to provide help to the genuinely needy and to discourage the formation of dependent habits. Moreover, moral and (where necessary) physical coercion had a valid role to play in forcing the willingly dependent to provide for themselves - in effect, in remoralizing them. All of these beliefs are well known, but how did this moral analysis of poverty actually work on the ground, that is, in face to face encounters between the upper classes and the poor? In particular, how did it function in the transactions between philanthropists and their clients and was it a credible analysis? Did the experiences of philanthropists bear out their beliefs that the poor did indeed require remoralizing? And what of their poor clients: when they resisted the philanthropists, did this result from a desire to live off the avails of others? Or were there other explanations to account for their behaviour?

An exploration of the ways in which this analysis actually functioned in encounters between rich and poor points toward some answers to another question - one, moreover, that is relevant today. Why did the moral analysis of poverty have such appeal? Not only did it become the dominant way of understanding poverty in the nineteenth century, but it has experienced a rebirth today. In the last two decades throughout the West, social programmes have been trimmed and tailored to discourage dependency. Those of us who study poverty in past times are very familiar with the arguments and judgements being made today. Britain's plans to overhaul the welfare state are only the latest instalment in this ongoing "morality tale." Tony Blair insists his government will continue to help those in genuine need, but plans coercive measures to force those who are able to work to do so since only individuals can pull themselves out of the morass of apathy and government handouts. Understanding such an analysis in its nineteenth-century context provides a useful perspective in evaluating this response today.

In attempting to explain how the moral analysis functioned in dealing with particular problems, one London charity makes an informative case study. The Mendicity Society grew out of several private investigations of London beggars 


\section{Left History 5.1}

begun by Matthew Martin in 1796. The records of this charity clearly document its priorities and intentions in helping its destitute clients; they also offer a rare window into the lives of the beggars themselves, of whom Martin estimated there were some 15,000 in London at this time. ${ }^{1}$ The Mendicity Society was a highly respectable charity, which is apparent from the membership of its board. The earls of Dartmouth, Hardewicke, and Chichester, and Earl Spencer all sat on it, as did the government ministers Nicholas Vansittart and George Rose, and the Evangelical businessman, Samuel Thornton. In the 1820s two of the sons of George III were the society's patrons: H.R.H. the duke of York, and upon his death, H.R.H. the duke of Clarence. The charity's priorities and analyses of the causes and proper treatment of destitution, moreover, were fairly typical of upper-class reformers of the period. ${ }^{2}$ The Mendicity Society was also, as its statistics indicate, a large and very active charity. As a case study to see how the moral analysis worked in practice, it is a good choice since it dealt with clients London beggars - who were generally considered to be among the most disreputable of the metropolitan poor.

Matthew Martin was able to procure money from the government with which he set up an office, and he began systematic enquiries between 1800 and 1803. ${ }^{3}$ In seven months, he examined 2,000 mendicants and 600 other paupers. ${ }^{4}$ Martin's purpose was the "'acquisition of information' [on begging] rather 'than the relief of distress," although private donations did enable him to offer some assistance to some beggars. ${ }^{5}$ This enquiry ceased when the government funding was exhausted, and Martin submitted his report in the form of a public letter to Lord Pelham, the Home Secretary, in 1803. During the severe depression of 1811, the government revived Martin's enquiry. Between 1811 and 1815, he examined some 4,500 beggars and raised a fund to provide for the most necessitous. ${ }^{6}$ Martin's enquiry lapsed again in 1815 , although he continued to agitate for a permanent body. He appeared as an expert witness before the Select Committee on Mendicity in the Metropolis, arguing for a permanent institution by which to distinguish worthy beggars from the unworthy. The idea was taken up in 1818 by a group of Londoners spearheaded by W.H. Bodkin. In March of that year they joined Martin to found what became a permanent body dealing with the problem of London beggars; that is, the Mendicity Society. As well as Martin, its board included the economist David Ricardo, and the police magistrate Patrick Colquhoun. ${ }^{\text {? }}$

The Society's approach to dealing with the problem of mendicancy was two-pronged, consisting of punishment of those whom it deemed fraudulent, and assistance and encouragement for those it thought worthy. It hired its own constables to patrol the streets looking for beggars who, when apprehended, 
were brought to the Society headquarters in Red Lion Square. If they were thought to be professional beggars, they were handed over to magistrates to be prosecuted for vagrancy. During its first fourteen years, Society constables apprehended more than 9,500 people, of whom 4,800 were convicted of vagrancy. ${ }^{8}$

In order to ensure it offered assistance only to the deserving, the Society distributed tickets to members of the upper classes, who were encouraged to give these, rather than money, to beggars. The beggars then turned in the tickets at the Society office where the circumstances of their cases were examined. The Society also operated a begging-letter department from January 1821 onward. Subscribers were encouraged to send in letters they had received soliciting assistance. These were investigated, and the subscribers notified as to the worthiness of the letter writers. In ten years, the Society examined some 28,000 letters, a number of which have survived in the papers of the second Earl Spencer. ${ }^{9}$

Although the ticket scheme could break down in the times of greatest distress - during the severe winter of 1819-20, for instance - and the Society take on "the aspect of an ordinary relief agency," recognition of moral status was a crucial and central part of its programme to eradicate mendicancy. ${ }^{10}$ In 1811 , Patrick Colquhoun and Nicholas Vansittart helped Martin revise his report of 1803 to Lord Pelham. Two thousand copies were printed and one copy sent to each member of both Houses of Parliament. " This document clearly set out the Society's analysis of the problem and the solutions it proposed, as did the Annual Reports the Society produced for the years from 1818 onwards.

Martin believed that there were a number of causes of begging. In the first place, poor relief was often inadequate. Many metropolitan parishes refused to give outdoor relief, insisting that paupers enter the workhouse, while distant parishes were hesitant to support paupers not living within their boundaries. More than this, however, he believed a combination of moral failings and economic factors could produce mendicancy. Among those he listed were

the want of regular employment; voluntary idleness, or delinquency; vicious habits and debts contracted at public houses; the purchase of articles of prime necessity by retail at little shops;... and debts incurred in consequence; the custom of pawning their clothes; the difficulty or impossibility of laying by a weekly sum sufficient to discharge the expense of lodging; sickness; and the fraudulent and oppressive conduct of others, in holding back their dues, cheating them of their property, etc. ${ }^{12}$ 


\section{Left History 5.1}

Martin clearly was aware that need, as well as depravity, caused mendicancy. When he appeared before the Select Committee, Martin said that 50 per cent of the time begging was "the effect rather of real distress than of any voluntary desire to impose." ${ }^{13}$ In the early 1820 s, the Society estimated that only 20 to 33 per cent of begging letters were from the worthy. ${ }^{14}$ Since industriousness alone was not a sufficient protection against falling into beggary, "a considerable degree of cautious discrimination" was necessary before judgement could be passed on beggars. ${ }^{15}$ In short, the moral condition of beggars had to be known.

The concern with moral condition was a constant theme, and by the mid 1820 s the Society was warning that habitual begging without exception demoralized the poor, since "the debasement so inseparable from so degrading a pursuit invariably paralyses the energies of industry and destroys every moral restraint." 16 Thus, it could not be assumed that an individual deemed worthy on one occasion would remain so thereafter. Several years later, the Society claimed that it alone ought to deal with beggars and that the public ought to restrict its charitable giving to "those unobtrusive sufferers who would disdain the casual relief solicited openly in the streets and whose misery springs not from idleness or vice, but from the occurrence of those calamities to which the rich and the poor are alike exposed." ${ }^{17}$ The message here was clear: the truly worthy poor did not beg and anyone who did was either depraved or in real danger of becoming so. Given this belief, it is not surprising that as early as 1823 , the distinction between worthy and unworthy mendicants was becoming blurred in the Annual Reports: the Society described its clientele as the debased and the "least culpable."18 Understandably, the Society focussed for the most part on ferreting out impostors, and saw its primary aim as the extirpation "as far as practicable" of mendicancy. ${ }^{19}$ By 1826 , it was describing itself as an "Auxiliary" to the forces policing London and claiming to be responsible for apprehending one-third of all those taken before the magistrates for vagrancy. ${ }^{20}$ Thus, detecting and punishing the unworthy became the great justification for the charity's existence. It became more and more complicated for supplicants to prove themselves worthy. As one regulation noted, "Where the character is bad, only one reference is required; but where the character is good, there should be two." 21 As a matter of course, the Society insisted that anyone, regardless of character, being provided with travelling expenses, be accompanied by one of its officers who bought the fare and then escorted the individual to the train or boat. Similarly, "If articles are to be redeemed by pawn, it is done by the Society's officers." 22 In short, the Society seemed to think its clients guilty until proven innocent and the clear expectation was that they would be found unworthy. 
What Martin, and subsequently, the Mendicity Society, sought to accomplish, was to bring beggars back within established systems of relief and to extend those systems to deal with the poor who did not fall into one of the various classifications for assistance. Thus, beggars who had a settlement in London or the Home Counties were to be sent to the parish to which they belonged for relief. Those whose settlements were farther afield were to be returned to their home parishes. ${ }^{23}$ Of the non-parochial poor remaining, the many who were Scottish or Irish would be returned to their native countries unless they could convince a magistrate they had good reasons for remaining. ${ }^{24}$ In all these ways, mendicants would "be put under proper regulations"; that is, they would be assisted within the established system, in ways appropriate to their condition. ${ }^{25}$

To accomplish this, the Mendicity Society's investigation of the character of the beggars had to be thorough and careful. It regularly advocated that "inquiry, rigid and minute inquiry, may invariably precede relief." 26 The first step in determining worthiness was the examination to which all applicants had to submit. Martin left a detailed description of the kind of questions asked. The first thing done was to note down the physical description of the applicant which he thought "might possibly be of some service to the Police." 27 The questions elicited information concerning the applicant's family life, employment history, settlement, and rent levels. Investigators wished to know whether poor relief had been received, and whether belongings had been pawned or the applicant was in debt. Equally important, a reference - "a creditable person who will vouch for your veracity and general character" - had to be given, and was checked. Finally, the mendicant had to explain how he or she came to be begging, and by whom and under what circumstances the ticket was obtained. ${ }^{28}$ The interview was followed up by at least one home visit, and often "repeated and unexpected visits" ${ }^{29}$ were deemed necessary. The visitors spoke to the applicant's referees, although a good reference was not considered sufficient proof of good character, as the Annual Report of 1823 made clear:

Nor ought implicit dependence to be always placed on the testimony of individuals, however respectable, to whom references may be made. Those individuals are sometimes the dupes of artful representations, and speak from an opinion hastily adopted, rather than from information actually obtained. ${ }^{30}$

To guard against misinformed or careless references, Society visitors also spoke to the applicant's neighbours, to the landlord and to local shop keepers. Its visitors, moreover, stood out in the labouring-class neighbourhoods where they conducted their investigations. As a mid-century admirer of the Society 


\section{Left History 5.1}

explained, the visitor "must be dressed as a gentleman, to give authority to his questions among applicants and his interviews with referees." ${ }^{31}$ In the determination of worthiness, then, Society applicants could expect little discretion or privacy.

Once the examination and the visits had been completed, character was assessed and appropriate treatment decided upon. In the early years, the mendicant initially received $3 \mathrm{~d}$. for returning the ticket. After 1818 , a "plain and wholesome" meal was given instead. ${ }^{32}$ If deemed worthy, and poor relief did not seem likely, then the applicant might well receive money, especially if it seemed a small advance would permit the beggar to set up him or herself in some kind of employment. The aim was twofold: to help the mendicant regain financial independence, but in achieving this, to strengthen moral character in order to ensure independence became permanent. From 1822 onward, the Society also provided short-term employment as "an immediate and infallible test of the sincerity" of its applicants, first in stone breaking and then in grinding flour to make its bread. ${ }^{33}$ It was careful to offer wages lower than normal in order, as Martin had explained, "to induce the parties to seek for or accept employment elsewhere." ${ }^{34}$ The Society estimated that at $8 \mathrm{~d}$. per ton, "an ordinary labourer... with common industry" could earn from 7s. to 9s. a week at stone breaking..$^{35}$ The Mendicity Society made no attempt to provide long-term treatment or assistance. Rather, it acted as a clearing house, identifying the moral condition of its clients and directing them to appropriate bodies and individuals for treatment.

The Society's analysis of mendicancy was influential: the rich and powerful sent their letters to be examined; the upper classes handed out its tickets; Parliamentary select committees listened to its leaders; titled grandees served on its board. The question to be asked, however, is how credible this analysis actually was. To answer this, the practices of the Mendicity Society need to be examined and its clientele identified.

In 1825, a concerted attack on the Society's practices was published anonymously in London. The Mendicity Society Unmasked was written by someone who clearly possessed inside knowledge of the Society's operations. The author claimed not to be motivated by acrimony, wishing instead to hold up "to public censure, the conduct of a powerful body, which is too frequently the cause of lasting injury to worthy and suffering individuals, who, fearing the finger of scorn would be pointed at them if they ventured to complain, submit in silence to the most barefaced injustice." ${ }^{36}$

The book points out that the Society was controlled by a small group of managers who were reappointed year after year. They oversaw and sometimes themselves made decisions concerning the worthiness of supplicants, and 
according to the author, were answerable to no one. ${ }^{37}$ The author claimed that the Society did some good "yet it does evil to a far greater extent" since it often turned away the innocent in its attempts to unmask impostors. ${ }^{38}$ This was so because the Society had moved beyond its original aim of weeding out those who practiced the trade of begging systematically. Rather, according to the author, "it goes to the unwarrantable length of saying what class of persons are, or are not to partake of the gifts of benevolence." 39 In support, the author quoted the Fifth Annual Report that a large percentage of clients come from "the lowest order, who seem to have no legitimate pretence for claiming such relief," and accused the Society of adopting an Indian caste system. ${ }^{40}$ Moreover, the author claimed the investigations were excessive. Instead of being content to prove that need was genuine and that the recourse to begging was not systematic, the Society pried "into all the secrets of a man's life and family," laying open "his entire history." The author pointed out that "Many very worthy people would almost prefer to perish to the laying open all their family affairs - they, therefore, demur to such questions as tend to it, and your visitors ignorantly conclude, that this apparent mystery is the result of crime." 41 The claim that the investigations were intrusive undoubtedly was true since, as seen earlier, the Society believed its clients either to be depraved or to be in imminent danger of becoming so. Hence, there was need for very close scrutiny.

The author of The Society Unmasked made other criticisms which focussed on the behaviour of its employees. Many of the decisions concerning the worthiness of clients were in the hands of the Society's clerks, who, in the opinion of the author, were not qualified to make such judgements and who frequently altered the reports containing the decisions of the begging letter committee to make them more pejorative. ${ }^{42}$

The author also reserved some scathing comments for the Society's visitors, who were called "ill bred and uneducated." ${ }^{43}$ In its early days, the Society had taken great care in selecting its visitors, but by 1825 it was no longer holding open competitions to fill visitor positions. Individuals were simply appointed: one was the 23 year old brother-in-law of the Society's assistant manager; another was a cousin of one of the officers and a bankrupt linen draper to boot. ${ }^{44}$ Even more disturbing was the change in the system of payment. Previously, the Society had paid its visitors $£ 100$ a year. By 1825 , it was beginning to pay them $2 \mathrm{~s}$. for every case investigated causing the author to wonder,

Is it not an inducement to hurry over a case,... and thus to pocket the two shillings at the expense of a suffering family? Certain I am, that those persons... whom you paid per case, investigated nearly twice as many cases in 


\section{Left History 5.1}

a week, as did those you gave a regular salary; and, moreover, that they

reported twice as many as 'worthless,' and 'undeserving attention. '45

These kinds of criticisms were potentially very damaging to the credibility of the Society's analysis. The author was very familiar with the quotidian operations of the Society, but possibly, in spite of assurances to the contrary, had an axe to grind. The text, while plausible, might be riddled with exaggeration and half truth. Other sources, however, tended to support some of the claims being made. It did not help the Society's reputation that its assistant manager, having provided gainful employment for his brother-in-law, was in the next year found guilty of defrauding the Society, and more culpably, of extorting money from its clients. $^{46}$

The Society's constables also came under attack for high handed and brutal behaviour. In an 1825 case, well publicised in the press, several constables tried to arrest a couple for begging. According to witnesses the constables began beating the man, who was holding a young child, hitting him repeatedly about the head with sticks. A gentleman riding by tried to intervene to stop the beating. The constables threatened to have the gentleman arrested for vagrancy and subjected him to "much gross abuse" and "opprobrious epithets." ${ }^{17}$ After the arrest, the magistrate hearing the case dismissed the vagrancy charge against the man, and instituted assault charges against the constables, one of whom was subsequently found guilty.

The Society chose not to respond at all to the charges made against its visitors in The Mendicity Society Unmasked. With respect to its constables, it merely stated that its officers were "humane and kind," and complained only that "much trickery was used in getting the indictments tried in the absence of the accused parties." ${ }^{48}$ While the trial did come on sooner than expected, trickery seems unlikely. The Old Bailey Proceedings for the period contain numerous references to defendants who had not expected their trials to take place so soon. In any case, the Society's response seems weak, if not evasive.

It seems clear that its officers did not always behave in an upright and professional fashion. Nor did the Society seem to possess adequate controls to enforce its standards of behaviour. The problem was exacerbated by the fact that the Society did not act in ways that inspired the loyalty of its employees. In 1829, for instance, one of its porters, Phillip Bragg, faced a family crisis: after a prolonged bout with cancer his wife died; his children then caught small pox and he fell deeply into debt trying to cope. The Society itself made no attempt to help Bragg, noting rather primly that "The Managers would feel much pleasure in rendering aid to his Family, but they are prevented by inability, also their pledge 
to the Public, that their funds are applicable only to the purposes, and objects of the Institution." 49 After noting with disapproval that none of the wealthy in Bragg's neighbourhood had helped the family, presumably "because the matter was not sufficiently made known," the assistant manager appealed to Lord Spencer to give them alms. ${ }^{50}$ In the eyes of the Society, employees in difficulty differed not at all from the beggars with whom it dealt.

All of these problems with its employees certainly call into question the Society's ability to determine the worthiness - the moral condition - of its clientele. If the Mendicity Society's data and reports are examined, moreover, these doubts are reinforced.

Data appended to Matthew Martin's 1803 Letter to Lord Pelham provide a window onto the clients of the Society as do the begging letters to Lord Spencer in the Althorp Papers, although a caveat should be noted. While the Society's investigations into the mendicants' stories weeded out a substantial number of impostors, those being interviewed undoubtedly tried to provide the Society with the kind of story they thought it wanted to hear. Nevertheless, the knowledge that claims would be investigated acted to ensure at least some truth even in most of the stories being made up.

A general analysis of Matthew Martin's first 2,000 examinations, and a more detailed breakdown of the first sub-group of fifty from these interviews, were included in the appendices of the 1811 revision of the Pelham Letter. ${ }^{51}$ In the summary of 2,000 cases, the pauper population was broken down according to sex and number of children. For the adults, marital status, provenance and nationality were also given. The sub-group summary provided age, sex, marital status, and the number of children per family. The parish of settlement was identified, as was the home address, the cause of distress, and the work skills possessed by the beggar. Character was described, the amount of monetary assistance received from the society and any further action taken in each case were noted. From this data it is possible to identify who the clients actually were.

The most striking thing to emerge from the 2,000 interviews was the fact that the vast majority of those applying for assistance were women. This was also the case in virtually every index of indigence during the period. In the large Westminster parish of St. Martin in the Fields, for instance, women formed 70 to 76 per cent of adult workhouse admissions, at least 80 per cent of out relief recipients, and between two-thirds and four-fifths of those removed throughout the war period. ${ }^{52}$ In this respect, Martin's data reflected typical patterns of indigence during the period. Men accounted for only 9.6 per cent of his clientele. Table One shows the percentages of married, single and widowed women and men who were interviewed. These 2,000 people had 3,096 children dependent 
upon them, for an average of 1.6 children per adult. Family size cannot be determined since the summaries do not state how many of the 2,000 people had children. Martin himself testified before the select committee on mendicity that few single women had children, and that the average number of children per woman was $1.5 .^{53}$ This would indicate that very few men had dependent children.

Table 1

Matthew Martin's Clients*

\begin{tabular}{|l|rr|rr|}
\hline & \multicolumn{2}{|c|}{ Women } & \multicolumn{2}{c|}{ Men } \\
\hline Married & 60.8 & $(1,100)$ & 52.0 & $(100)$ \\
\hline Widowed & 32.1 & $(581)$ & 24.4 & $(47)$ \\
\hline Single & 7.0 & $(127)$ & 23.4 & $(45)$ \\
\hline
\end{tabular}

$n=2,000$

* The first figure is the percentage of each sex, that in parentheses is the actual number Source: Martin, Pelham, Appendix C.

Women - especially the married - also predominated in the sub-group of fifty. The median age of these wives was 36.5 years. Only single women were younger with a median age of 19 years (See Table Two). The widowed of both sexes and the few married or single men who applied, all tended to be older, with average ages in the fifties. Married women also had by far the most children - on average, two per woman in contrast to married men who only had 1.3. Widows, also being older, had far fewer dependent children, only 0.3 per woman on average. Widowers, on the other hand, seem to have had many more children than their female counterparts -1.2 on average. This figure is somewhat misleading, however, since only two of the six widowers accounted for all the children. Indeed, the very low numbers of men applying (10 in this sub-group of 50) makes it difficult to isolate male patterns with any degree of reliability.

From the information just given, it seems that it was the most vulnerable who were seeking help. Women with children, and older men and women all had a greater likelihood of becoming Martin's clients. This pattern is even more apparent if the reasons for destitution given in the sub-group summary are examined. More than half the wives -10 of 18 - said their husbands were either sick, absent or refused to support them. Another said her husband had been married before, presumably indicating a refusal to support. Also contributing to the financial problems of these eleven women was the fact that they had more children than the group of married women as a whole -2.6 children per woman on average. Another woman claimed her own sickness and yet another, the sickness of her child, had contributed to their difficulties. Five gave want of work as 
Table 2

Characteristics of Applicants

\begin{tabular}{|c|c|c|c|c|c|}
\hline Group & Number & $\begin{array}{l}\text { Av. Age/ } \\
\text { Mean Age }\end{array}$ & $\begin{array}{l}\text { Number } \\
\text { of } \\
\text { Children }\end{array}$ & $\begin{array}{l}\text { Place of } \\
\text { Origin by } \%\end{array}$ & $\begin{array}{l}\text { Av. } \\
\text { Relief } \\
\text { Given }\end{array}$ \\
\hline Wives & 18 & $37.4 / 36.5$ & 2.0 & $\begin{array}{l}38.8 \text { home* } \\
27.8 \text { distant } \\
22.2 \text { foreign } \\
11.1 \text { unsure }\end{array}$ & $61 / 3 \mathrm{~d}$ \\
\hline Widows & 16 & $57.9 / 57$ & 0.3 & $\begin{array}{r}50.0 \text { home } \\
37.5 \text { distant } \\
6.3 \text { foreign } \\
6.3 \text { unsure }\end{array}$ & $5^{1 / 4} \mathrm{~d}$. \\
\hline $\begin{array}{l}\text { Single } \\
\text { Women }\end{array}$ & 6 & $26.7 / 19$ & 0 & $\begin{array}{l}83.3 \text { homw } \\
16.7 \text { unsure }\end{array}$ & $3 \mathrm{~d}$. \\
\hline Husbands & 3 & $53.3 / 52$ & 1.3 & $\begin{array}{l}66.6 \text { home } \\
33.3 \text { foreign } \\
\end{array}$ & $3 \mathrm{~d}$. \\
\hline Widowers & 6 & $59.8 / 57.5$ & 1.2 & 16.7 home & $6 \mathrm{~d}$. \\
\hline Single Men & 1 & 50 & 0 & 100 distant & $1 \mathrm{~s}$. \\
\hline
\end{tabular}

$\mathrm{n}=50$

* home $=$ parishes in London and Home Counties, distant $=$ all other English and Welsh parishes, foreign $=$ lrish, Scottish, and all other countries, unsure $=$ entitled to a settlement, but unsure which parish. Source: Martin, Pelham, Appendix B.

a major cause of destitution, while another simply claimed hard times. Finally, one said pawning, robbery and fire had brought the family low, and another gave debt as the reason. ${ }^{54}$ Thus, almost two-thirds of these families did not have an active male bread winner, but tended to have more children than the group as a whole. Slightly less than 40 per cent of the married women examined were unable to contribute financially to the family's income either because they could not get work, or because they or their children were ill.

In the reasons widows gave for their destitution, there are similar patterns of vulnerability, but with one difference. A quarter of these women gave no reason for their destitution. ${ }^{55}$ In every instance they were removed to their parishes, and in only one case was a character assessment made, indicating that examiners decided very quickly that for these women, parish relief was the proper solution. These women had in common that they were completely alone with neither husband nor children; and secondly, that they came from local parishes. Only two other women were removed to their parishes, and in both instances they were described as aged and incapable. Whereas the six wives who were removed to their parishes were carefully examined (only one had a char- 
acter which was "not fd. ${ }^{56}$ ), the Society seems to have been much more cursory in its dealings with women who were totally alone or incapable. This was perhaps an implicit acknowledgement of the enormous difficulty women who were alone faced in achieving subsistence. Why waste interview time on what were clearly hopeless cases?

Of the widows for whom reasons for destitution were given, the loss of the husband was the most common cause. This was so in 25 per cent of the cases, while age was a factor for 18.8 per cent. Illness and want of work were causes of destitution for another 12.5 per cent in each instance. Finally, one woman cited debt as the cause of her difficulties. ${ }^{57}$ These applicants clearly had few options in making ends meet.

If the ten men are examined as a single group, it is again apparent that these were people with few options in making ends meet. Seven of the ten were either ill or physically unable to work. Another was described as 'incapable,' and the ninth gave family sickness and want of work as the source of his difficulties. For only one man was the source of distress not explained. Given that men earned substantially more than women when the former could work, this very heavy concentration of physical incapacity was not surprising.

Vulnerability and lack of options are common themes among these clients. This was reinforced by the nature of the occupations they gave (see Table Three). Among the widows and married women, needlework and spinning were the major trades, and both of these were low paid occupations suffering from labour surpluses. They were often incapable of providing workers in them with a living wage. With the exception of the woman who turned her ability to write to good stead, none of the others possessed skills which could have brought greater security. ${ }^{58} \mathrm{Among}$ the men, unskilled work was the norm - even the shoe trade worker only mended, and did not make, shoes. Life was precarious for all in the labouring classes at this time, especially for those in semi-skilled work, so it is not surprising that Martin's clientele would be drawn from these ranks, and from trades in which pay was low and work irregular.

A somewhat different situation existed with respect to begging letters. The authors of these letters were regarded with deep suspicion by the Mendicity Society. In part, this resulted from the Society's belief that the vast majority of these letter writers were frauds -66 to 80 per cent according to various estimates in the 1820s. The Society also thought the investigation of these letters was a test of its own worthiness since they were "transmitted by persons of rank and influence, and it could not be doubted, that their opinion of the Society would be materially affected by the manner in which the [begging letter] committee acquitted themselves. ${ }^{\circ 9}$ This meant that the letter writers, even more than street beggars, would be subject to close scrutiny. 
Table 3

Occupations of Mendicity Society Applicants

\begin{tabular}{|l|r|l|r|}
\hline \multicolumn{1}{|c|}{ Women } & & \multicolumn{1}{c|}{ Men } & \\
\hline Needlework & 10 & Labour & 4 \\
\hline Spinning & 5 & Mending shoes & 1 \\
\hline Labour & 2 & Road work & 1 \\
\hline Field work/gardening & 2 & Gardening & 1 \\
\hline Washing/charing & 2 & Incapable & 2 \\
\hline Sweeping streets & 1 & Not given & 1 \\
\hline Selling hare skins & 1 & & \\
\hline Making pens/writing & 1 & & \\
\hline Not given & 16 & & \\
\hline
\end{tabular}

$\mathrm{n}=50$ Source: Martin, Pelham, Appendix B.

The letters that have survived in the papers of the second Earl Spencer number some 88 for the years from 1824 to 1828 . They are similar in one respect to the cases in the summary. The overall pattern of applicants who were the most vulnerable members of society, and who had few of the options normally available to the labouring classes, is even more apparent. The letters gave the history of how the applicant came to be distressed. They are revealing, but also frustrating since they are less systematic and consistent in the range of information provided than were the summaries. Thus, the figures in the following discussion may well be under-estimates.

Once again, women at 65 per cent, formed the vast majority of applicants. ${ }^{60}$ Eight people were repeat applicants, with illness being the cause of the second request in five instances. Indeed, among the reasons given for destitution, illness of the individual, or in the family, was most commonly cited. This was the case for 33 of the 80 individuals, that is, 41 per cent. Twelve applicants blamed age and the inability to work for their problems, while sixteen married women were in dire straits at least in part because they lacked a male breadwinner (thirteen were widowed, one had a husband in prison and two had been deserted). Eight applicants claimed to be unable to find work and seven also cited debt as a cause of their difficulties. Finally, 49 per cent of the applicants had children, for an average of 3.8 each.

These letters reveal the process that led to destitution, and the steps by which the applicants had sought to avert it. If illness and family breakup most often led to financial difficulty, the problem was often initially met by pawning and selling furniture and clothing (there were references to these activities in 21 


\section{Left History 5.1}

cases). Credit was also used, and as difficulties worsened, the debt load became part of the problem. In five instances, the Society investigator noted that the applicant had no friends or that the family was dead or abroad and hence unable to assist the person in distress.

The applicants in these letters were vulnerable -63 per cent in all were either elderly, ill or had illness in the family, or lacked a male breadwinner. The majority of these letter writers seemingly required no moral reformation. Nevertheless, one cannot simply assume this holds overall for the letter writers whom the Society investigated. Only 25 per cent of the letters in the Althorp Papers came from people whom the Society deemed unworthy - a virtual reversal of the claims the Society made in its Annual Reports concerning the proportions of worthy and unworthy letter writers. It is impossible to know whether a substantial number of the letters Lord Spencer submitred to the Society for examination have simply been lost or misplaced. If this were so, their inclusion might provide the proportions of unworthy letter writers the Society claimed to find. Then again, it might not. Whether the Society was even competent to identify worthiness, of course, has already been called into question. If the begging letters in the Althorp Papers cannot actually disprove the Society's analysis, they do not contribute to proving it either. Rather, their effect is unsettling.

The last piece of evidence that might shed light on the credibility of the Society analysis consists of information on its applicants provided in the Annual Reports. In these, the Society broke down its clientele into a number of categories. By assembling those described as unworthy (according to the Society's lights), percentages of such people can be worked out for each year. The number of impostors, those who refused poor relief when it was offered, those who had sufficient means to support themselves, those who refused work offered by the Society and those who came once but did not return to be investigated can be totaled up to arrive at an 'unworthiness percentage.' If the first five years are considered - 1818 to 1822 - only twice did the percentages of 'unworthiness' reach 50 per cent, the level claimed to be the case by Matthew Martin. In 1819, 54 per cent and in 1822, 57 per cent of the Society's applicants fell into one or another of the above categories. In both of these years, the percentages were inflated by those who had failed to return when directed to do so. Without this category, the percentages of those thought unworthy dropped to 27 per cent and 14 per cent respectively. In the other three years, 1818, 1820 and 1821, the percentages of those thought unworthy were substantially lower, 35 per cent, 26 per cent and 38 per cent respectively. In these years, the proportion of those not returning was also much lower: 4 per cent, 9 per cent, and 7 per cent respectively. In 1825 , the year which saw the various complaints against the Society's 
practices, 60 per cent of the clientele fell into these categories. Without the nonreturners, however, the proportion dropped to 34 per cent.

Nowhere does the Society offer proof that those who did not return acted from depravity. Rather, it assumed that they had something to hide, noting suspiciously that "they have been careful to withdraw precisely at the period when intelligence respecting them might be expected to arrive."61 The question remains, however, whether there might not be another equally plausible explanation to account for this behaviour. I shall return to this point shortly.

There are other difficulties in trying to interpret the Society's figures. It is possible that those deemed unworthy are hidden in other categories; some of those who were referred to their parishes, for instance, may have been considered unworthy. Nor did the Society see fit in its Annual Reports to record the numbers of women and children with whom it dealt. In short, as presented, its figures cannot be checked to see whether they bear out the Society's claims concerning the percentages of the worthy and unworthy making up its clientele.

The fact that the Society was responsible to no one and declined to answer the charges against its clerks, visitors and constables throws real doubt on its claims to thorough and careful investigation of its clients. The vulnerability of the applicants revealed in Martin's data, the much lower percentages of those deemed unworthy in the letters in the Althorp Papers, and the inability to test the Society's claims against the Annual Report statistics, call into question its claims that those deemed unworthy constituted at least half of its clientele. While individually, none of these problems destroys the Society's credibility, together they form a pattern which seriously undermines its analysis. This in turn gives rise to a question: if there are serious doubts concerning the Society's analysis of mendicity, can an alternative explanation be put forward to account for the behaviour of its clients?

As it happens, one can. The poor had good reasons for not returning to be investigated, for refusing poor relief and for deserting the Society's work force. To understand this behaviour, it is necessary to consider at some length plebeian notions concerning reputation and its role in making ends meet. In an environment where work was irregular even for the most skilled, and where low wages were the lot of most in the labouring classes, people could not expect to get by solely through individual initiative and hard work. ${ }^{62}$ While these were necessary, they were not a sufficient guarantee against destitution. As a result, the labouring classes relied on neighbourhood resources, mutuality, pawning and credit, in order to weather short-term difficulties. Mutuality meant that women and men lent money and goods to neighbours and friends, and performed services for them. ${ }^{63}$ This was not a form of charity, however, since there was a 


\section{Left History 5.1}

clear expectation that these favours would be reciprocated when needed. Pawning, another important resource, was the regular recourse of many families, and an option in emergencies for the better off. Finally, credit tabs at local shops were well nigh universal, and landlords often extended credit to their lodgers in periods of difficulty. These resources could be exhausted, however, when families or individuals were engulfed by long-term problems. No one could afford to support a family for months on end, for instance.

These resources were available for the most part only to those who enjoyed a good reputation among their neighbours. Peter Earle has compiled, from London Consistory Court depositions, a description of virtues for women and men which were respected by the labouring classes. These documents were drawn from an earlier period, and in them the neighbours of the disputants described good women thus:

A very sober and regular person and using to work much at her needle...a poor but honest woman and works hard for what she getts...a sober and discreet woman of good credit and reputation amongst her neighbours...a loving dutyfull and obedient wife to her husband... a sober, vertuous, prudent carefull and frugall woman... a carefull industrious and saveing person...just, honest and dutiful to her parents... of unspotted life and conversation... as good humour'd a woman as ever lived in the world. ${ }^{64}$

Bad women, on the other hand were either sexually promiscuous or had the reputation for being so, were quarrelsome, abusive, lewd in their language, violent, rash and disrespectful of their husbands. For men, neighbourhood respect was gained through fair and just business dealings, hard work, honesty and regularity in habits, and kindness and respect for their wives. Men who did not provide for their families or who were lazy and idle, who engaged in debauched talk, especially with disreputable women - or consorted with them, who drank too much, or who abused their wives and families and employees beyond what the neighbourhood thought proper forfeited their good reputations. $^{65}$

Reputation also had a very practical dimension. As Earle put it,

The maintenance of character or reputation was an essential safeguard against times of trouble when the opinion of one's neighbours could be literally the difference between life and death. Many a defendant at the Old Bailey won a not guilty verdict from a jury or relative mercy from a judge by the willingness 
of neighbours to come and speak in court for his or her character....Reputation was equally important in less dramatic circumstances. It could make the difference between a job and no job, tick or no tick at the local chandler's shop or alehouse, a pension or free accommodation at the expense of the parish rather than a spell in the workhouse or eviction from the parish for the destitute. Neighbours looked after their own, but they only looked after those of whom they approved. ${ }^{66}$

Aside from Earle's evidence, the importance of reputation can be seen in accounts and interviews given by labouring-class people. William Hart, a cooper who lived from 1776 to 1857 , wrote an autobiography. In it he says that as a young man in London, he lodged with a former shopmate. The latter helped him find a small house to rent and loaned him a bed until he could afford to buy one of his own. In slack seasons, Hart was repeatedly able to find work through other old shopmates. The fact that he was deeply religious, sober and industrious no doubt gave others confidence in recommending him for work even when they did not know him that well. ${ }^{67}$

Henry Mayhew's interviews with the London poor in the mid-nineteenth century also reflect the continuing importance of reputation in mutuality networks. A male tailor, who sublet part of his house, recounted how he had looked after two brothers, his lodgers, for three weeks during the cholera epidemic. To prevent them starving, he was forced to pawn his bed and bedding. This tailor estimated that the two owed him $£ 213 \mathrm{~s} .9 \mathrm{~d}$., but had not paid him back. Nevertheless, he said of them,

I think they're honest young men and would pay me if they could. Maybe they're ashamed to write to me - yes, I dare say they are, for they were good young men - though I never had their money, I'll say that of them. ${ }^{68}$

Obviously, the two had been men of good reputation which even the nonpayment of the debt did not change. Certainly, not being known and respected could have dire consequences for those who fell ill. At eighteen, William Hart contracted small pox a month or so after he had moved to the town of St. Albans. No one would take him in. His master, for whom he had worked for several weeks, did try to assist him, but the old woman with whom he lodged refused to let him stay since she "kept a shop and was afraid of losing her customers." 69 Hart was able to return to the town where he had served his apprenticeship and to receive assistance there from friends and from the parish. $\mathrm{Had}$ he been forced to remain in St. Albans, the consequences could have been disastrous. As Hart observed, 


\section{Left History 5.1}

it was a favourable circumstance (though it appeared a calamitous one at the time) that no person could be found to take me in at St. Albans, for if they had the expense would have been very great to me, and I had not much money, being out of my time only a few weeks. ${ }^{70}$

Being known and respected was, then, crucially important in times of distress. In the most extreme instance, it could mean the difference between life and death.

Reputation also played a role in pawning. Certainly, in pawning belongings, being known in the neighbourhood was a great help. In the first place, women - and most pawners were women - loaned each other items to pawn. ${ }^{71}$ In 1800, for instance, when Mary Miller was charged with theft of clothes and furnishings, she defended herself by claiming that the woman bringing the charges [Susannah Pope] had told her "anything in her [Pope's] room was at my service; and she lent me several things herself to pledge. I intended to get them out after Christmas." ${ }^{\prime 72}$ While the fact that Miller seemed to have pawned almost all of Pope's belongings might cast doubt on this particular claim, there were numerous examples of this kind of behaviour. Later in the same year, Margaret Lane was found not guilty of stealing a greatcoat after she explained that "a sister-in-law of mine gave me the coat to pledge, I did not know it was stolen." 73 Pawning, then, could become part of mutuality networks. More than this, however, being known in the neighbourhood meant that neighbours and friends could actually do the pawning for an individual. Hannah Smith, in 1781, pawned some stockings for Ann Braidy because the latter "was rather dirty." ${ }^{14}$ Smith, presumably somewhat cleaner and hence more respectable in appearance, would have been able to get a better price from the pawnbroker since she looked less needy. The advantages of this kind of service could be decidedly material.

Being known and well thought of by the pawnbroker also lessened the likelihood of being suspected of stealing the goods on offer. One pawnbroker said of a customer subsequently charged with theft, that she was his neighbour, and that he had always taken her "for a very honest woman." Another similarly placed pawnbroker stated that the woman accused of theft had been his customer for twelve years and that he had never "heard anything amiss of her before." $\mathrm{.75}$ All in all, having a good reputation in the neighbourhood offered a number of advantages to those engaging in pawning.

Another crucial resource helping women make ends meet, and one entwined with pawning, was the establishment of credit with local shops. It was especially important that a woman be able to buy food when the family was 
experiencing difficulty. In some instances, families were able to establish fairly long-term credit both with shops and landlords. These tenants were generally employed in highly seasonal occupations, and it was understood that credit extended during the slack time would be made good in the busy season. As Gareth Stedman Jones pointed out for a slightly later period,

In order to escape starvation and in order to insure against the possibility of being thrown onto the streets at various periods of the year, it was essential to establish good credit relations with the landlord, the local shop, and the local pub. Landlords in poorer areas would be paid up in the summer. Local stores and pubs came to similar arrangements. 'Being known' in a district was thus of considerable economic importance. ${ }^{76}$

This was not just the province of labourers, moreover. After Francis Place and his wife had pawned all their belongings during the eight months he was unemployed in 1793, their landlady [who evidently kept a shop] allowed them credit for bread, soap, coals and candles to the extent that when Place regained work as a tailor he was in debt $£ 6 .{ }^{77}$ The period of credit was considerably longer than that which most in the labouring class could expect. Place was a particularly respectable man, and no doubt this weighed in his landlady's decision to be generous.

For most people, credit was allowed to run only a week or so, especially at small chandlers' shops (the chief provisioners to the labouring classes), where the proprietor would face ruin if accounts remained unpaid. If credit was refused, a woman might well return "to leave a Shift, Cap, Apron or Pocket as a pledge til the Money is paid." " Indeed, it was often cheaper to pawn an item and to use the money advanced to pay off a credit account, rather than to let it run. ${ }^{79}$

Thus, these resources were intertwined: mutuality could shade into pawning, and pawning become part of the credit cycle. All were necessary in the uncertain London labour market if people were to overcome short-term difficulties. In order to have access to borrowing networks and credit it was necessary that the individual or the family be known and approved of in the neighbourhood. Neighbours obviously were less likely to lend assistance to strangers or to those who did not act, in the words of Hans Medick, to maintain "the bonds of kinship, neighbourhood and friendship." ${ }^{80}$ Shopkeepers and landlords were more willing to extend credit to those who had successfully worked off credit accounts and rent debts in past. Even pawning was embedded in a nexus of neighbourhood relationships in which reputation played a central role.

Being known and respected in the neighbourhood, then, meant having 


\section{Left History 5.1}

access to resources which were crucially necessary in making ends meet. Great care had to be taken in order to retain one's good character, not the least because life was so very public at this time. In Westminster, the labouring classes lived in houses subdivided among several families. On average, nine or ten people from two or three families lived in each house, usually in apartments of one or two rooms. ${ }^{81}$ The houses were often very close to one another. In one Consistory Court case, a witness claimed to be able to hear whatever was said by her neighbour in the house next door. ${ }^{82}$ Indeed, of twenty-one defamation cases involving labouring-class people heard between 1780 and 1820, individuals in twelve of them admitted to having overheard or spied on their neighbours.

Since virtually no labouring-class apartments had running water and food could not be kept for long, women especially, spent much time in the streets - on the way to shops or at communal pumps. Indeed, two-thirds of the altercations involving defamation occurred in the streets or in shops or a pub. The public nature of life also meant that neighbours were very aware of the comings and goings of individuals, which is reflected in the Consistory Court cases. In one instance, a witness said a number of neighbours came to their doors to watch the dispute. ${ }^{83}$ In another, a male witness called the customers in a pub outside to watch a quarrel ${ }^{84}$ In a third case, a shopkeeper standing at his door observed a competitor in the same alley refer a customer to a third shop and let loose a volley of abuse as a result. ${ }^{85}$ In yet a fourth, a witness claimed the whole court frequently had been disturbed by the riots made by "a troublesome woman" named Mary Shadd. ${ }^{86}$

In such an atmosphere, where individuals were constantly under the watchful eye of their neighbours, reputation was something to be guarded. Indeed, those who were the targets of insults could be forced to defend their good names by others also affected by the abuse. In one instance, a servant was told by her employer to clear up the matter or lose her job. ${ }^{87}$ In another case, a husband refused to allow his wife to return home until she had cleared her reputation. ${ }^{88}$ It mattered how one was regarded in the neighbourhood. To be thought virtuous, hardworking and peaceable often brought material advantages. The absence of such good opinion, on the other hand, could be a distinct disadvantage in trying to make ends meet. In any case, as V.A.C. Gatrell has pointed out in another context, the maintenance of 'face' was a crucial part of the self-respect of plebeian Londoners. As Gatrell observes, "To triumph over affliction, to refuse surrender, to reject mediocrity, and still to mock and laugh was to achieve the main distinction plebeian life could offer." ${ }^{\prime 29}$

Not surprisingly, in this kind of neighbourhood life, people who fell into destitution often tried to hide it from their neighbours, especially if forced to 
pursue options of which the neighbourhood might disapprove. In a slightly later period, Henry Mayhew found that people who were forced by need to beg often tried to disguise this. He said,

the sale of small articles in the streets may, perhaps, be an excuse for begging; but in most cases I am convinced it is adopted from a horror of the workhouse, and a disposition to do, at least, something for the food they eat. Often it is the last struggle of independence - the desire to give something like an equivalent for what they receive. ${ }^{y 0}$

Mayhew said people did this from "the aversion to be thought a common beggar." ${ }^{\prime 1}$ They clearly did not wish to be recognized by friends and acquaintances. One woman whom Mayhew interviewed, for instance, said she sold matches in the street. She lived in Whitechapel, but said she went to Shoreditch to sell them, "thinking I would not be known." 92 The next week she returned to the same spot, "holding my head down like a bulrush, for fear that somebody would pass that knew me." ${ }^{93}$ Begging, moreover, was not a popular option among the destitute. Of 62 poor needlewomen who attended a meeting Mayhew had called, ten had been forced to enter a workhouse, 19 had pawned their work, 31 had gone without food for a day, but only three women admitted to begging in the streets. ${ }^{94}$ This reluctance to beg had been a constant, moreover, throughout the period. In 1783, for instance, Sarah Leach had told the court at the Old Bailey that she had shoplifted some cloth because "I was ashamed to beg" even though in great distress. ${ }^{95}$ Similarly, as the cases described in the Annual Reports of the Mendicity Society reveal, people sometimes waited until they were half-starved and all but naked before finally resorting to begging.

In an environment where reputation in the neighbourhood was very important, and begging an activity to be concealed if possible, the Mendicity Society practice of home visits by strangers, clearly from a higher class, would have excited comment by the neighbours. Similarly, appeals to 'creditable persons' in the neighbourhood - including landlords and shopkeepers - also helped to broadcast the individual's plight, as did Society officers redeeming goods from the local pawn shop. These Society practices made the individual's indigence public knowledge, and consequently made it difficult to retain access to neighbourhood resources needed to regain and to maintain financial independence. Since the vast majority of Mendicity Society applicants came from the most vulnerable sectors of the community, such public investigation of character must have seemed spurious and demeaning as well as economically harmful.

To return finally to the point of this long detour: is there an alternative 
explanation for the behaviour of the Society's clients who did not return to be investigated or who refused work? Yes, and it runs like this. Behaviour, which from above seemed to be depraved, was in reality an attempt to maintain independence. People declined to be investigated because it would have left them publicly stigmatised in their neighbourhoods. Neighbours would have been less likely to include them in borrowing networks; shopkeepers, at the very least, would have hesitated to grant credit; and pawnbrokers, sensing desperation, likely would have made lower valuations on goods. Those not returning to be investigated can be seen as protecting their future ability to make ends meet; they were, in fact, showing foresight in planning ahead. It made good sense to turn in the ticket, accept $3 \mathrm{~d}$. or the meal, and then to scarper. Those who deserted the Society workforce may also have been demonstrating sound financial sense. In London's uncertain labour market people needed to be available immediately when work turned up on short notice, as it so often did. If they spent the day toiling for the Society's wretched wage, they ran the risk of not hearing about chances to work in their own trades and not being available to work when it was offered. It must often have seemed wiser to gamble on work turning up, especially if there had been rumours of the possibility in the neighbourhood. It is ironic, surely, that while the Society was deathly concerned not to become a permanent prop for mendicants, many of these people wanted Society assistance on even shorter terms than it was being offered. Moreover, in acting to maximize their ability to make ends meet and to safeguard the resources necessary to continue to do so in future, I would argue that these people were demonstrating the very values the Society was so convinced they needed to learn: foresight in maintaining independence and a willingness to work whenever the opportunity offered.

Thus, the Mendicity Society's analysis of indigence was problematic on several grounds. It was inappropriate in that it neither addressed the needs nor recognized the realities of plebeian life. Moreover, moral regeneration would not serve to increase the few options these people had to achieve subsistence. Finally, the Society's prescriptions were not merely inappropriate; they were actively harmful. In making the moral condition of potential clients apparent to its officials, the Society also made the neighbourhood aware that the individual or the family had been tipped into destitution. This in turn meant that these people likely had more difficulty in recovering their place in the community.

In spite of the wrongness of the moral analysis of poverty, it had a hale and hearty life in the nineteenth century. The question is why. Certainly, contemporary critics called the Society's practices into doubt, but not its clearly unproven analysis. In part, this resulted from the self-validating nature of the analysis. The 
failure to eradicate, or even diminish, the problem of poverty through attempts to promote independence was proof that the poor were even more unredeemed than previously believed. In effect, failure gave the entire effort even greater legitimacy, and it justified redoubled efforts to reform the poor.

Moreover, this analysis seemed to match the temper of the times. As Mitchell Dean has pointed out, demands for the moral reform of the poor were part of the system of regulation peculiar to the mode of liberal governance emerging in the early nineteenth century. As Dean says,

pauperism is as much about 'morals,' forms of every- day life, families, breadwinners, households, and self-responsibility, as economics, the state, poor laws, and poor policies. It is about the formation of particular categories of social agent, and of specific class and familial relations, in so far as they are promoted by governmental practices. ${ }^{96}$

He continues that,

in regards to matters of poverty, the private sphere is not so much one of personal freedoms and rights but of the economic responsibilities of a certain category of social agent, the male breadwinner. To achieve this 'responsibilisation' of the poor, the liberal mode of government, far from guaranteeing certain rights, must oppose arguments for, and remove practices which secure rights to subsistence for various social categories. ${ }^{97}$

In tune with the demands of liberalism, the moral analysis of poverty was also in tune with the dominant assumptions and priorities of the upper classes.

Finally, even though this analysis did not operate terribly well in the case study examined, and even though there were good explanations for the plebeian behaviour that seemed depraved from above, it could still retain its appeal because it silenced those best placed to point out its limitations: the poor. By defining the poor as defective, the moral analysis prevented them from being active partners in the social dialogue determining the understanding and treatment of poverty.

In the end, then, we are left with a self-affirming hypothesis reflecting the assumptions and priorities of those with power and marginalising the voice of those whom it denigrates. That the moral analysis of poverty has once again become central in the formulation of social policy must surely concern anyone who believes that all members of a society are full citizens possessing rights as well as moral responsibilities. This analysis may seem compelling to those who 


\section{Left History 5.1}

are comfortably placed in a society, but as long as social policy is developed in this kind of discursive vacuum it will do little to help poor men and women overcome poverty.

1 Matthew Martin, Letter to the Rt. Hon. Lord Pelham on the State of Mendicity in the Metropolis (London 1803), 19.

2 The priorities and analyses of poverty reformers are discussed in full in J.R. Poynter's classic study, Society and Pauperism (London 1969). A more esoteric account is to be found in Gertrude Himmelfarb's The Idea of Poverty (New York 1984).

3 Martin, Pelham, 6.

4 Ibid., 6-7.

5 lbid., 10.

6 David Owen, English Philanthropy 1660-1960 (Cambridge, Mass. 1964), 110.

7 Ibid., 111.

8 lbid., 112

9 lbid.

${ }^{10}$ Owen, Philanthropy, 112.

1 Matthew Martin, Substance of a Letter, Dated Poet's Corner, Westminster, 3 March, 1803, to the Rt. Hon. Lord Pelham, on the State of Mendicity in the Metropolis (London 1811), iii.

12 Ibid., 11.

13 Matthew Martin, quoted in "The Report of the Select Committee on Mendicity in the Metropolis" BPP HC 1814-15 III, 235-236.

14 Fourth Report of the Society for the Suppression of Mendicity (London 1822) [hereafter Fourth Report], 21, and Seventh Report, 24.

15 Martin, Substance of a Letter, 10.

16 Fifth Report, 2. [my emphasis]

17 Seventh Report, 29.

18 Fifth Report, 2.

19 Ibid.

20 Eighth Report, 25 and 29. The Metropolitan Police Force was founded in 1829.

21 Anon., The Mendicity Society Unmasked (London 1825), 25.

22 Second Report, 8.

${ }^{23}$ Martin was under no illusions that the poor law system was adequate to the task of reforming, or even adequately assisting the mendicants. He thought many overseers were unqualified, underpaid, inexperienced and served only because compelled to, with the result that their duties could not be "regularly and constantly well performed" (Pelham, 16). He resisted a detailed critique of the poor law system, however, because he thought to do so would be 'invidious.'

${ }^{24}$ Martin, Substance of a Letter, 17.

25 Ibid., 19.

26 Fifth Report, 18.

27 Martin, Substance of a Letter, 5.

28 Ibid., 22-24.

29 Fourth Report, 21.

30 Fifth Report, 18

31 Anon., The Practice of the Mendicity Society (London 1847), 41.

32 Third Report, 10-11. 
33 Fourth Report, 12.

${ }^{34}$ Martin, Pelham, 24.

35 Fifth Report, 9.

36 Anon., Mendicity Society Unmasked, 1.

37 Ibid., 3-4.

38 Ibid., 5.

39 Ibid., 15.

40 Ibid., 15-16.

41 Ibid., 24-25.

42 Ibid., 13-14.

43 lbid., 21.

44 Ibid., 32, 38.

45 Ibid., 32.

46 See Case 11647, Thomas Fitzgerald, Althorp Papers, G 145 (1826) and Ninth Report, 23-27.

47 Ninth Report, 44.

48 Ibid., 50.

49 Letter from J. Stephens, Althorp Papers G 155 (17 August 1829).

50 lbid.

51 Martin, Substance of a Letter, Appendices C and B respectively.

52 The exception to this pattern was 1815 when demobilization and depression began to swell male figures. Thus, women formed 65 per cent of adult admissions in 1815, and 73 per cent of adult recipients of out relief in that year. Removal orders for 1815 have not survived. Westminster City Archives F4019-4026, F2075-2076 and F6075-6078 respectively.

53 B.P.P., Select Committee on Mendicity, Vol. III, 238.

54 In a number of instances more than one reason was given.

55 In the one other case, for which this is true, the woman was dead.

${ }^{56}$ I am assuming that 'not fd.' means 'not found', since unfavourable character was indicated by the abbreviation 'unfav.'

57 Once again, a number of women gave more than one reason for their plight.

58 With respect to hare-skin sellers, Henry Mayhew (who discussed both buyers and sellers) said they were generally poor, old or infirm. See Mayhew, London Labour and the London Poor, Vol. II (New York 1968), 111.

59 Fourth Report, 21.

60 Since sending a letter was less humiliating than direct begging in the street, it may be that men were somewhat less hesitant to take part in the activity. Given the small number of cases being examined, however, it is probably not wise to regard these figures as being absolutely representative.

61 Fourth Report, 11.

62 For the economic conditions in London during this period, see L. D. Schwarz, London in the Age of Industrialization (Cambridge 1992).

63 Ruth Smith and Deborah Valenze have argued for the crucial importance for mutuality in the lives of plebeian women in "Mutuality and Marginality: Liberal Moral Theory and Working-Class Women in Nineteenth-Century England," Signs, 13, (1988), 277-98. For its importance in the late nineteenth and early twentieth centuries, see Ellen Ross, "Survival Networks: Women's Neighbourhood Sharing in London before World War I," History Workshop Journal, 15 (1983), 4-27, and Love and Toil (New York 1993). I would argue that it was also important in the lives of plebian men, although here it operated less within the neighbourhood context and more within work.

64 Peter Earle, A City Full of People, Part Two, Ch. 1, "People," 186.

65 Ibid., 186-87. 


\section{Left History 5.1}

66 Ibid., 173.

${ }^{67}$ Pat Hudson \& Lynette Hunter, eds., "The Autobiography of William Hart, Cooper, 1776-1857, A Respectable Artisan in the Industrial Revolution," London Journal, 7, (1981), Part I, 157.

68 E.P. Thompson \& Eileen Yeo, eds., The Unknown Mayhew (Harmondsworth 1974), Letter VII - 9 November 1849, 161-162.

69 Hart, "Autobiography," 152.

70 Ibid., 153.

71 Melanie Tebbutt, Making Ends Meet (New York 1983), 37-67. While Tebbutt makes this claim based on evidence from later in the nineteenth century, there is little reason to assume the situation was substantially different at the beginning of the century. Tebbutt also points out that many of these women sought to keep their pawning a secret from their spouses, which may also in part account for the relatively few references to it in labouring class autobiographies.

72 Old Bailey Proceedings, 1800, case 106, 96-97.

73 Ibid., case 420, 379.

74 Ibid, 1781, case 104, 82.

$75 \mathrm{Ibid}, 1800$, Cases no. 106, 97 and case 708, 579.

76 Gareth Stedman Jones, Outcast London (Harmondsworth 1971), 87-88.

77 Francis Place, Autobiography' of Francis Place, Mary Thale, ed. (Cambridge 1972), 117.

78 Anon., Low Life; or; One Half of the World Knows Not How the Other Half Lives (London 1764), 216.

79 Tebbutt, Making Ends Meet, 16.

80 Hans Medick, "Plebian Culture in the Transition to Capitalism," in Raphael Samuel \& Gareth Stedman Jones, eds., Culture, Ideology \& Politics, (London, 1982), 92.

81 For population figures, see B.P.P., Accounts \& Papers, 1801, VI, 823-827; Abstracts, Population Returns 1812, XI, 199; Accounts \& Papers, 1822, XXI, 651-633. For density, see "Report of a Committee of the Statistical Society of London, on the State of the Working Classes in the Parishes of St. Margaret and St. John, Westminster," and C.R. Weld, "On the Condition of the Working Classes in the Inner Ward of St. George's Parish, Hanover Square" in Royal Statistical Society, London Journal, Series A, Vol. 3 (1840) \& 6 (1843) respectively. An analysis of the figures in these pieces shows that there were on average 2.4 and 2.1 families per house respectively in these parishes.

82 Greater London Record Office, Consistory Court Depositions, Jones vs Parker, February 1805, X19/151, 143-151.

83 Ibid., Hart vs Aaron, December 1785, X19/147, 193.

84 Ibid., Palmer vs Williams, December 1782, X19/146, 368.

85 Ibid., Nowlan vs Rose, January 1793, X19/150, 347.

${ }^{86}$ Ibid., Goulee vs Shadd, May 1805, X19/214, 653.

87 Ibid., Dinnis vs Groves, February 1789, X19/148, 208-209.

88 Ibid., Goulee vs Shadd, p.654.

89 V.A.C. Gatrell, The Hanging Tree (Oxford 1994), 144.

90 Mayhew, London Labour and the London Poor, Vol. I, "Street Sellers of Stationery, Literature, and the Fine Arts," 322.

91 Ibid., 323.

92 Thompson \& Yeo, Unknown Mayhew, "Letter XI - 23 November 1849," 209.

93 Ibid.

94 Ibid., 216.

95 Old Bailey Proceedings, February 1783, Case 258, 386.

96 Mitchell Dean, The Constitution of Poverty (London 1991), 3.

97 Ibid., 13. 